- YEARB̈OOKK of ANTITRUST and REGULATORY

STUDIES

www.yars.wz.uw.edu.pl
Peer-rêviēwed scientific periodical, focusing on legal and economics issues of antitrust and regulation. Creative Commons Attribution-No Derivative Works 3.0 Poland License

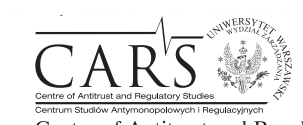

Centre of Antitrust and Regulatory Studies, University of Warsaw, Faculty of Management www.wz.uw.edu.pl

\title{
2008 and 2009 EU Competition Law and Sector-specific Regulatory Case Law Developments with a Nexus to Poland
}

\author{
by
}

Dagmara Kośka, Krzysztof Kuik*

\section{CONTENTS}

I. Introduction

II. Case summaries

1. Antitrust

2. State aids

3. Mergers

4. Electronic communication - regulatory framework

4.1. Progress Report 2009

III. Tables

4.2. Judgments in regulatory infringement cases

\section{Abstract}

The 2008 issue of YARS contained an overview of EU law developments in the period of time from 2004 to 2007. This overview covers the years 2008-2009. It confirms that State aid cases remained numerous (6 in total) and that the Commission's enforcement activities in the area of State aid control continued at a similar pace as before. With respect to other areas of competition law and policy, the overall picture shows a relatively high level of scrutiny in mergers (5) and antitrust cases or inquiries (2).

Moreover, EU Courts adopted several decisions in Polish cases, notably in the regulatory field (electronic communications) and State aid control (partial annulment in Huta Częstochowa (Operator) as well as the rejection of a request for interim

* Dagmara Koska and Krzysztof Kuik are officials of the European Commission (DG Competition). The views expressed in this overview are the authors' personal views, and do not necessarily represent the position of the European Commission. The authors are grateful to Anna Mościbroda for her input to this paper. 
measures in Technologie Buczek). The regulatory court cases show the Commission's consistency in pursuing Member States in their failure to implement or to correctly implement the EU Electronic Communications package. In the state aid related Huta Czestochowa (Operator) judgement, the General Court (GC, formerly the Court of First Instance, CFI) partially annulled the scrutinised Commission decision since the Commission failed to identify the actual benefit related to the receipt of the aid in question. The jury is still out in the case concerning Technologie Buczek because the interim measures judgement says little about the potential outcome of the pending main appeals.

\section{Résumé}

Le YARS de 2008 contenait un aperçu des développements du droit de l'UE pendant la période de 2004 à 2007, alors que celui-ci couvre les années 2008-2009. Il confirme que les cas d'aides d'État sont restés nombreux (6 au total) et que la mise en œuvre du contrôle des aides d'État par la Commission a continué au même rythme. En ce qui concerne les autres secteurs du droit de la concurrence et de la politique de concurrence, le nombre de contrôles des concentrations et des cas ou des enquêtes antitrust est relativement élevé (2).

En outre, les cours de l'UE ont rendu plusieurs arrêts dans des cas polonais, notamment dans le domaine réglementaire (communications électroniques) et du contrôle d'aides d'État (l'annulation partielle dans Huta Częstochowa (opérateur) ainsi que le rejet d'une demande de mesures provisoires dans Technologie Buczek). Les arrêts dans le domaine réglementaire montrent la cohérence de la Commission dans les actions contre les États membres qui ont manqué à leur obligation de mettre en oeuvre, ou de mettre en ouvre correctement, le Paquet Télécom de l'UE. Dans l'arrêt Huta Częstochowa (opérateur) concernant les aides d'État, le Tribunal (précédemment le Tribunal de Première Instance, TPI) a partiellement annulé la décision de la Commission puisque la Commission n'a pas réussi à identifier l'avantage réel de la réception de l'aide en question. Le jury est toujours en train de délibérer dans le cas concernant Technologie Buczek parce que l'arrêt sur les mesures provisoires dit peu sur les résultats potentiels des appels principaux en cours.

Classifications and key words: Access Directive; active ingredient; airline industry, antitrust; bankruptcy; broadband; collective management; competition law; copyright; divestiture; e-communications; economic crisis; electronic communications; EU competition law, European Commission; fine; Framework Directive; full-function joint venture; insurance; interconnection; interim measures; liquidation; merger; national regulatory authority, NRA; patent; performing right; pharmaceutical industry; pharmaceutical sector inquiry; Polish Law on telecommunications; Polish shipyards; recovery decision; recovery of the aid; regional aid; remedies; reproduction right; restructuring aid; shipyards; State aid; subscriber. 


\section{Introduction}

The 2008 issue of YARS provided an overview of EU law developments in the period from 2004 to 2007. The cases described in that overview brought about important legal clarifications. Some raised important legal issues. Others contained a Polish element (eg, a merger which affected Polish markets). State aid matters (of which there were 9) clearly outweighed other cases, including mergers (5), antitrust (1) and regulatory cases (1).

This overview confirms that State aid cases remained numerous and the Commission's enforcement activities in the area of State aid control (6 in total) continued at a similar pace in 2008 and 2009. The period included significant State aid decisions regarding shipyards and regional aid to Dell. In particular, the Dell Poland case is noteworthy as the Commission's first in-depth assessment of regional aid to large investment projects under the 2009 Guidance Paper (including a more economic approach to analysing State aid). However, the overall picture also shows relatively high scrutiny in other areas of competition law and policy, including merger (5) and antitrust (2) cases or inquiries. The authors expect that this development, combined with a high number of cases pursued by the Polish Competition Office (UOKiK) under EU competition law ${ }^{1}$, will provide useful and specific guidance to Polish market participants in their efforts to comply with applicable EU rules and regulations.

This is the first time the overview covers EU jurisprudence. The EU Courts adopted several decisions in Polish cases, notably in the regulatory field (electronic communications) and State aid control (partial annulment in Huta Częstochowa (Operator) and rejection of interim measures in Technologie Buczek). The regulatory judgements illustrate the Commission's consistency in pursuing Member States' lack of or incorrect implementation of the EU Electronic Communications framework. Poland is not the only Member State that has been subjected to the Commission's vigilance in this regard. In the Huta Czestochowa (Operator) judgement, the General Court (GC) (formerly the Court of First Instance, CFI) partially annulled the Commission decision, as it could not identify an advantage which would result from the acquisition by the special purpose operating company, of the non-steel assets of Huta Częstochowa. The jury is still out in the case concerning Technologie Buczek, as the interim measures judgement says little about the potential outcome of the pending main appeals.

\footnotetext{
${ }^{1}$ See an overview of UOKiK's cases in its annual reports available at: http://www.uokik.gov. pl/sprawozdania_z_dzialalnosci_urzedu.php.
} 


\section{Case summaries}

\section{Antitrust}

\section{CISAC Prohibition Decision - collective management of copyright (performing rights)}

In July 2008, the European Commission adopted an antitrust prohibition decision addressed to a number of European collecting societies (societies) managing the rights of music authors, including the Polish collecting society, Zwiazek Autorów i Kompozytorów Scenicznych (ZAIKS) (the CISAC Decision) ${ }^{2}$. The CISAC Decision concerned collective management, administration and licensing of performing rights (part of the exclusive copyright in musical works $^{3}$ ) for satellite, cable and internet (on-line) uses ${ }^{4}$.

The CISAC Decision aimed to promote choice for the rights holders (authors and publishers) regarding which society they wanted to entrust with the administration of their rights (the prohibited restrictions prevented any such competition between the societies). It also sought to create conditions for competition between the mandating and mandated society for licensing the repertoire of the former. The prohibited restrictions protected a monopoly of each national society to license the world repertoire to commercial users located in its territory. Finally, the CISAC Decision sought to create conditions

2 Commission decision of 16 July 2008 relating to a proceeding under Article 81 of the EC Treaty and Article 53 of the EEA Agreement (Case No. COMP/C2/38.698 - CISAC).

3 A performing right is an exclusive copyright vested in musical works, which enables an author to authorise or prohibit the public performance of his/her work by a commercial user, and to receive royalties for exploitation of the work. It is a term which is widely used by the industry and corresponds to the right of communication to the public (including making the right available) under the Directive 2001/29/EC of the European Parliament and of the Council of 22 May 2001 on the harmonisation of certain aspects of copyright and related rights in the information society, OJ [2001] L 167/10. In Europe, it is commonly considered that online exploitation of musical works implies both their communication to the public and their reproduction. For that reason, the online exploitation requires both performance and mechanical rights licences (the mechanical right corresponds to the reproduction right under the 2001 Copyright Directive).

${ }^{4}$ The CISAC Decision relates to the exploitation of a performance right of musical work over the Internet - i.e. on-line use - either as a stand-alone service (download, streaming, etc.) or part of a satellite broadcast or cable retransmission. These three modes of exploitation have specific features distinguishing them from other, traditional types of use (off-line use, e.g. in discothèques), notably the possibility of remote monitoring beyond national boarders. Therefore, the Commission takes the view that on-line exploitation should not be treated 'mechanically in the same way' as off-line exploitation. 
for developing licences covering more than one territory for cable, satellite and on-line users ${ }^{5}$.

Traditionally, the management, administration and licensing of copyright is organised locally. An author becomes the member of a society, usually the society operating in his/her Member State. He/she entrusts this society with an exclusive worldwide mandate to manage his/her rights. The catalogue of all rights assigned by all members to their society constitutes the society's 'own' repertoire.

A performing rights' collecting society exploits its repertoire by directly licensing rights to perform within its domestic territory. However, the societies also license their repertoires internationally by entering into reciprocal representation agreements (reciprocals) with other societies around the world. By means of such agreements, societies have mandated each other with the authority to license each other's repertoires to users in each other's territories. As a result of the network of reciprocals, each society could offer the repertoire of authors represented by all the other societies (i.e. world repertoire), but only to the interested commercial users operating within its domestic territory.

The CISAC case has it origin in two complaints related to the CISAC model contract $^{6}$. The first complaint was filed by RTL Group in November 2000 against the German collecting society, GEMA, and GEMA's refusal to grant RTL an EU wide licence covering its own repertoire and the repertoire of other European societies. The second complaint was filed in April 2003 by Music Choice Europe against CISAC, and concerned the CISAC model contract.

On 31 January 2006, the Commission issued the Statement of Objections (SO) against CISAC and 24 EEA collecting societies (all CISAC members). The SO raised concerns as regards the membership restriction ${ }^{7}$ and territorial restrictions of the CISAC model contract, and their implementation in the reciprocals concluded by the EEA societies.

Following the SO, CISAC and 18 of the societies offered commitments ${ }^{8}$, whereby they proposed to remove the membership and exclusivity clauses

5 A. Andries, B. Julien-Malvy, 'The CISAC decision - creating competition between collecting societies for music rights' (2008) 3 EC Competition Policy Newsletter.

${ }^{6}$ CISAC (International Confederation of the Societies of Authors and Composers) is an umbrella association for the authors' collecting societies. It proposes to its member societies a model reciprocal representation agreement, which is largely followed in the reciprocals between the CISAC members.

7 The 'membership clause' in the reciprocals of 24 societies prevented authors from affiliating themselves with a society other than their domestic one or becoming members of several different EEA societies.

8 The commitments were offered in March 2007 and were market-tested by the publication of the notice on 9 June 2007, OJ [2007] C 128/12. The market participants who submitted their observation considered that the exceptions and conditions listed in the commitments would result in few, if any, commercial users obtaining the multi territorial licence. 
from the model contract and reciprocals. The societies also offered to grant multi-repertoire, multi- territorial mandates to licence on-line, satellite and cable retransmission services to societies that fulfil certain minimum qualitative criteria ${ }^{9}$. In response to the proposed commitments, the Commission received over 80 observations. It concluded that the proposed commitments would not give an appropriate answer to all competition concerns raised in the SO.

In light of the outcome of the market test of the proposed commitments, and on the basis of the remaining serious concerns, the Commission adopted a prohibition decision against EEA societies. The CISAC Decision reaffirms the position that certain clauses in the reciprocals concluded between EEA societies (namely, membership and territorial exclusivity clauses) constitute an infringement of Article 101 TFEU and Article 53 of the EEA Agreement ${ }^{10}$. The Decision prohibits those two clauses for all, off-line and on-line, modes of exploitation, and requires their removal. The CISAC Decision also condemns the concerted practice between the 24 EEA societies on the territorial delineation of mandates incorporated in reciprocals as regards satellite, cable and internet (on-line) uses. The CISAC Decision found that the societies had coordinated their behaviour, thereby restricting the territorial scope of mandates granted to each other to the domestic territory of the mandated society. As a result, they partitioned the EEA into national markets. The CISAC Decision required a review of the reciprocals in a non-coordinated manner and, as it did for the membership and exclusivity clauses, obliged their addressees to refrain from any act or conduct having the same, or similar, object or effect.

As one of the addressees of the CISAC Decision, ZAIKS, the Polish authors' collecting society, was found in breach of EU competition law by incorporating the two restrictive clauses in its reciprocals with other EEA societies and by

9 Those criteria related, among other requirements, to the administrative and technical infrastructure, capabilities, certain service levels as regards the tariffs and distribution, and transparency.

10 Collecting societies have a long history of persistent application of membership restrictions. In the 1970s and the 1980s, the Commission clarified that the societies, as dominant undertakings, cannot discriminate on the basis of an author's nationality (GEMA I, Case IV/26.760, decision of 2 June 1971) or refuse to conclude a management contract with a non-resident right-holder (GVL, Case IV/29.039, decision of 29 October 1981; judgment of the Court of 2 March 1983). Furthermore, in GEMA II (Case IV/26.760, decision of 6 July 1972), the Commission provided guidance regarding the duration and the scope of the contract between the societies and the authors by means of which the authors mandated the societies with the administration of their rights. GEMA II allowed authors to withdraw one or more categories of rights (the so called GEMA categories of rights) or rights for certain use of works after a certain period of time (up to 3 years). In the Daft Punk case (Case COMP/37.219, decision of 12 August 2002), the Commission confirmed that it should be possible to withdraw certain rights from collective management. 
participating in the concerted practice of territorial delineation of mandates. ZAIKS appealed the CISAC Decision on 22 September $2008^{11}$, requesting also interim measures ${ }^{12}$. On 14 November 2008, the General Court (GC) rejected ZAIKS's application for interim measures ${ }^{13}$.

Like many European societies, ZAIKS has also been subject to the scrutiny of the national competition authority (Urzad Ochrony Konkurencji i Konsumentów; hereafter UOKiK). In recent years, UOKiK found several ZAIKS practices restrictive against, depending on the case, either commercial users or its own members. On 16 July 2004, UOKiK, acting upon the complaint by the music group 'Brathanki', adopted a prohibition decision ${ }^{14}$ which established that ZAIKS had abused its dominant position by (i) requiring its members to give ZAIKS an exclusive mandate to administer both performing and mechanical rights and (ii) accepting the mandates to administer the right on condition that the right holder transfers all of his/her rights to ZAIKS. UOKiK also imposed a fine of PLN 500,000 ${ }^{15}$. In a decision of 29 August 2008, UOKiK prohibited the agreement between ZAIKS and Stowarzyszenie Filmowców Polskich (SFP) fixing the level of copyright royalties due for the use of the audiovisual works and the related refusal to negotiate, as well as imposed a fine of PLN 1 million ${ }^{16}$. On 21 July 2009, UOKiK adopted a decision which found that ZAIKS had abused its dominant position by imposing on authors who were not members of ZAIKS an excessive duration of the agreement mandating ZAIKS with administration of their rights, without the possibility of terminating such agreement before the lapse of the five-year term ${ }^{17}$. The decision also imposed a fine of approximately PLN 400,000 on ZAIKS.

The CISAC Decision, as well as the national case-law developments, show clearly the growing importance of collective rights management and related issues in Europe. Issues arising from collective management of copyrights have been identified as one of key obstacles to the digital single market. A framework directive on collective rights management is one of the flagships of the Commission's Digital Agenda. As stated by the Vice President of the European Commission and Commissioner for Competition, Joaquin

11 Case T-398/08.

12 Case T-398/08 R.

13 ZAIKS did not sufficiently substantiate the serious and irreversible damage that it would suffer in case of the implementation of the decision before the final judgement.

14 Decision RWA-21/2004.

15 The 2004 Decision was upheld by the Polish Supreme Court on 6 December 20007 (III SK 16/07). On 24 June 2008, UOKiK imposed an additional fine of approximately PLN 1.5 million for non-implementation of its previous decision (Decision RWA-19/2008).

16 Decision DOK-6/2008.

17 Decision RWA-10/2009. 
Almunia ${ }^{18}$, 'collecting societies serve a vital role but the way they manage licensing agreements needs to change. The fragmented national monopoly model and the de facto allocation of customers can no longer stand in their current form'.

\section{Pharmaceutical industry - Pharmaceutical sector inquiry}

In the field of antitrust, 2008 and 2009 were marked by an extensive inquiry launched by the European Commission into the European pharmaceutical sector. The inquiry began in January $2008^{19}$, when the Commission carried out unannounced inspections at the premises of a number of pharmaceutical companies producing innovative medicines (the so-called originators) and generic medicines (the so-called generic companies) ${ }^{20}$. The objective of the inquiry was to examine the reasons why fewer new medicines were brought to market and why generic entry seemed to be delayed in some cases. The preliminary results were published in November 2008 and the final report was published in July 2009. The inquiry has shown a number of shortcomings in the pharmaceutical sector. It has demonstrated that originator companies use a range of instruments to extend the commercial life of their products without generic entry for as long as possible. The Commission also identified a number of regulatory issues regarding patents and patent litigation in Europe.

The inquiry points to the fact that Poland is one of the countries with the highest generic penetration in Europe (56\% in value terms, $73 \%$ in volume terms as compared to less than $20 \%$ by value in Belgium, Finland, France, Greece, Ireland, Italy and Spain, and 20-40\% in Austria, Denmark, Germany, the Netherlands, Portugal, Sweden, Hungary and the UK). The varying level of generic penetration in the EU is influenced, among other factors, by the different public policy choices made by the Member States (e.g. the Polish patent law as well as patent laws in Hungary, Slovenia and Portugal give generics a head start by allowing testing in connection with an application for marketing authorisation before the patent's expiry).

18 J. Almunia, 'Competition in Digital Media and the Internet', UCL Jevons Lecture London, 7 July 2010.

19 Commission Decision of 15 January 2008 in Case COMP/39.514, initiating an inquiry into the pharmaceutical sector pursuant to Article 17 of Council Regulation (EC) No 1/2003; see Report from the Commission on Competition Policy 2008 and Commission Staff Working Document accompanying the Report from the Commission on Competition Policy 2008 of 27 July 2009, $\operatorname{COM}(2009) 374$ final.

20 This was the first time that the Commission launched a sector inquiry with upfront inspections. 


\section{State aid}

In the field of State aid control, the sudden onset of the financial and economic crisis in 2008 shifted the focus onto the role of State aid policy in the context of crises ${ }^{21}$. Despite this and the high workload related to the crisis, the Commission maintained its scrutiny over cases where State aid had been granted before the crisis, such as the cases of State aid to the Polish shipyards and the recovery case of Technologie Buczek. The Commission continued shaping State aid control rules by adopting several guidance papers, including Guidance on in-depth assessment of regional aid to large investment projects ${ }^{22}$. The principles detailed in these guidelines were applied for the first time in the Dell Poland case.

\section{Gdynia, Gdańsk and Szczecin shipyards (2008-2009)}

Article 107(1) TFUE prohibits any aid granted by a Member State in any form whatsoever which distorts competition and has an effect on trade between Member States, subject to a limited number of exceptions set out in Article 107(3) TFUE. The objective of a derogation foreseen for rescue and restructuring aid to ailing companies (Article 107 (3)(c) TFEU) is to assist a company in financial difficulty. However, certain conditions need to be fulfilled. These conditions are regulated by the Guidelines on State aid for rescuing and restructuring firms in difficulty ${ }^{23}$, which also apply to the shipbuilding sector ${ }^{24}$.

To be eligible for restructuring aid, a firm must qualify as a firm in difficulty. The granting of aid must be conditional on implementation of a restructuring plan, which must be sound, far-reaching and enable the company to restore viability within a reasonable timeframe ${ }^{25}$. The restructuring plan should be based on realistic and verified assumptions and should be sufficiently robust to withstand small changes in the macroeconomic environment. A further

21 See Report from the Commission on Competition Policy 2009 para. 7 et seq. and Commission Staff Working Document accompanying the Report from the Commission on Competition Policy 2009 of 3 June 2010, COM(2010)282 final para. 3 et seq.

${ }^{22}$ Communication from the Commission concerning the criteria for an in-depth assessment of regional aid to large investment projects, OJ [2009] C 223/3.

${ }^{23}$ OJ [2004] C 244/2. The Commission extended the validity of the Guidelines, which would have expired in October 2009, until October 2012, OJ [2009] C 156/3.

24 The Framework on State aid to shipbuilding (OJ [2003] C 317/11) refers to the Guidelines on State aid for rescuing and restructuring firms in difficulty as the relevant legal basis for assessing rescue and restructuring aid.

25 Restoration of viability means that the company, after completing restructuring, is able to cover all its costs and generate a sufficient return on capital to compete on its own merits. 
condition is that the amount of aid must be limited to the strict minimum of the restructuring costs necessary to enable restructuring to be undertaken. ${ }^{26}$ The beneficiary is expected to make a significant contribution (normally more than $50 \%$ ) to the financing of restructuring from its own resources or from external financing at market conditions. Lastly, measures must be taken to mitigate any adverse effects of the aid on competitors ${ }^{27}$. This usually means limiting the company's market share after the end of the restructuring period. The restrictive nature of these conditions stems from the fact that restructuring aid is generally considered to lead to serious distortions of competition.

The shipyards in Gdynia, Gdańsk and Szczecin have been in difficulty since the 1990s. Since 2002, they benefited from significant amounts of State support which sustained their presence on the market, e.g., through non-enforcement of public liabilities, capital injections, loans, tax write-offs and advance payment guarantees. Without such support, the shipyards would not have been able to conclude contracts ${ }^{28}$. In April 2004, Poland notified restructuring aid for the three yards ${ }^{29}$ and the Commission opened formal investigations in June 2005. Poland submitted a restructuring plan for the yards in 2005 and several revised restructuring plans later on, after Poland's decision to privatise the shipyards. Given the complexity and political sensitivity of the issues, the Commission's investigation lasted over four years and involved intensive exchanges between the Polish government and the Commission on the details of the proposed restructuring plans for the yards.

On 6 November 2008, the Commission decided that no suitable marketbased solution which would be in line with the EC Treaty (now TFEU) could be found for the shipyards in Gdynia and Szczecin. The Commission rejected the most recent version of the restructuring plan, since it had not been demonstrated that (i) this plan would restore the long-term viability of the two yards, (ii) the aid would be limited to the minimum necessary and (iii) provision would be made for measures to limit the distortion of competition created by the aid (in essence, the restructuring would have been financed entirely by State aid). As a result, the Commission adopted negative decisions

26 Point 43 of the Guidelines on State aid for rescuing and restructuring firms in difficulty.

27 Points 38-42 of the Guidelines on State aid for rescuing and restructuring firms in difficulty.

${ }^{28}$ Gdynia shipyard benefited from aid measures amounting to EUR 700 million and from production guarantees of EUR 916 million (both in nominal value). Szczecin shipyard received aid of EUR 1 billion as well as production guarantees of EUR 697 million (in nominal value). Gdańsk shipyard had been benefiting from State aid amounting to approximately EUR 90 million since 1 May 2004 (see para. 171 of the Commission Decision of 22 July 2009).

29 Cases C-17/2005, C-18/2005 and C-19/2005, respectively. As regards Gdańsk shipyard, Poland notified additional new aid in November 2006. 
with respect to these two yards and required Poland to recover all State aid unlawfully granted to the yards since May 2004.

As regards recovery of State aid, instead of using the standard recovery provisions, the decisions envisaged an implementation by way of an asset sale and subsequent liquidation of assets ${ }^{30}$. The aim of such a solution was to minimise the adverse economic and social consequences of the recovery. Poland made a commitment to ensure that the recovery would be implemented by way of a sale of assets or small bundles of assets in an open, transparent, non-discriminatory and unconditional tender. The proceeds from the sale of the assets would be used to repay creditors, including the recovery claim of the State related to the unlawful aid. The buyers of assets would be able to continue an economic activity at the shipyards' sites without having to repay the State aid.

The Commission imposed the following conditions ${ }^{31}$ to ensure that the asset sale would not lead to circumvention of the recovery order:

- the asset packages on offer would be sufficiently small so as not to constitute an organised part of an undertaking or a business;

- the sale would be conducted by an independent administrator;

- a monitoring trustee would be appointed, whose main role was to give the Commission a detailed insight into the process and to ensure that the process was conducted in line with the agreed conditions;

- no write-off or repayment of public liabilities or repayment of private creditors was permissible and no new aid would be granted as part of the process;

- no new contracts would be concluded; and

- all public claims would be treated as they would in ordinary insolvency proceedings.

Poland agreed to complete the sale by the end of May 2009 and has organised two tendering rounds so far. Nevertheless, the Commission had to extend the implementation deadline of the recovery decision due to complications in the sale process (to date, not all assets have been sold successfully) ${ }^{32}$.

As regards the Gdańsk shipyard, the new majority owner ISD Polska, a subsidiary of the Ukrainian steel producer Donbas and formerly a minority shareholder in the Gdańsk shipyard, submitted a revised version of a standalone

30 This model had been developed in the Olympic Airways cases, see Cases N 321/2008 - Olympic Airlines, N 322/2008 - Olympic Airways Services ( $1^{\text {st }}$ part) and N 323/2008 - Olympic Airways Services (2 ${ }^{\text {nd }}$ part).

31 See EUROPA Press Release IP/08/1642.

32 The Commission decision envisages that, should the asset sale be unsuccessful, Poland would put any remaining assets into liquidation, see EUROPA Press Release IP/08/1642 and MEMO/08/680. As of 31 December 2009, Poland has not launched insolvency proceedings. 
restructuring plan for Gdańsk Shipyard in May 2009 (2009 Restructuring Plan). The Commission accepted the 2009 Restructuring Plan and, on 22 July 2009, decided that State aid for the plan's implementation is compatible with the common market. However, the implementation of the State aid was authorised under the condition that the 2009 Restructuring Plan and the envisaged compensatory measures be duly implemented and that the envisaged ratio of the company's own contribution free of State aid to the restructuring costs be respected. Poland was obliged to submit regular detailed reports to the Commission, enabling it to monitor implementation and financing of the restructuring plan, as well as compliance with arrangements for capacity reduction and production restrictions.

The Polish shipyard cases should be seen against the background of a number of similar past State aid cases in the shipbuilding sector in Europe in which the Commission has adopted both positive and negative decisions. On the one hand, there were a number of negative decisions ordering repayment of past aid (for example, the Spanish public shipyards IZAR, German Kvaerner Warnow Werft and the Hellenic shipyards ${ }^{33}$ ). On the other hand, the Commission approved State aid granted to five shipyards in Eastern Germany that had undergone an in-depth restructuring in the 1990s, benefiting from substantial amounts of State aid of approximately EUR 3 billion.

There are significant differences between the cases of the Gdynia and Szczecin shipyards and the East German privatisations. The latter were conducted more swiftly. Public monetary support was used not only to support their operations, but also for a genuine modernisation of the yards. The restructuring was accompanied by a substantial capacity reduction of $40 \%$ overall, including a closure of two shipyards. By comparison, the Gdynia and Szczecin shipyards had benefited from prolonged operating aid and had been artificially kept afloat for many years. The aid had not been used for modernisation and restructuring. The long privatisation effort had not attracted an investor capable of preparing a convincing restructuring plan that would permit the yards' operation without continuous recourse to State aid ${ }^{34}$. Moreover, the contribution of the shipyards would have been less than $15 \%$ of the restructuring costs (as opposed to $50 \%$ required by EU State aid law). Lastly, restructuring of the Gdynia and Szczecin yards would not be timely, as a positive pay-back on equity would be achieved only in 2018. The Gdańsk yard was in a different situation as it was smaller than the two other yards, already privatised in 2007 , with the necessary private capital, and received a considerably lower level of subsidies.

33 See EUROPA press releases IP/04/1260 and IP/08/1078.

${ }^{34}$ It should be noted that the Commission required that financing of restructuring was secured up-front to avoid company's recourse to additional State aid to complete its restructuring. 


\section{Technologie Buczek (2008)}

As a preliminary matter, rescue and restructuring aid cases in the steel sector are extensively covered in the contribution to the 2008 issue of YARS. The 2008 contribution discussed, inter alia, the Commission's negative State aid decision regarding the Polish seamless tube producer Technologie Buczek Group (the Buczek Decision) ${ }^{35}$.

The Buczek Decision was appealed by Huta Buczek (hereafter, HB) ${ }^{36}$, Technologie Buczek (hereafter, TB) ${ }^{37}$ and Buczek Automotive (hereafter, $\mathrm{BA})^{38}$ on a number of grounds. In parallel, BA and HB applied to the GC for interim measures in form of a suspension of operation of the Commission's recovery decision ${ }^{39}$. On 13 February 2008, the GC suspended the execution of the Buczek Decision until the final order concerning interim measures. On 14 March 2008, the GC dismissed BA's and HB's applications for interim measures. In both cases, the GC held that the applications were partly inadmissible (as regards pleas raised for the benefit of other group members ${ }^{40}$. It duly dismissed BA's application for interim measures, considering that (i) BA had filed for its own bankruptcy and did not withdraw its application after the GC's February suspension order (demonstrating the lack of urgency) and (ii) BA failed to provide detailed financial information about the new group of companies to which it belonged (over $50 \%$ of BA's assets were acquired by Severstallat); thus, demonstrating the lack of serious and irreparable harm ${ }^{41}$.

In its interim measures application, HB argued that it was in a dire financial situation and would thus need to file for insolvency should the Commission's decision be implemented. Insolvency and ensuing exit from the market would take place before the GC's decision on the appeal and would constitute a serious and irreversible harm. The GC considered, however, that HB did not prove that it would need to exit from the market. First, the insolvency

35 On 23 October 2007, the Commission adopted a negative decision with recovery regarding Technologie Buczek Group (TB) and its subsidiaries Huta Buczek (HB) and Buczek Automotive (BA) (Case C-23/2006). According to the decision: (a) approx. PLN 1.4 million (plus recovery interests) had to be recovered from TB; (b) PLN 13.6 million (plus recovery interests) had to be recovered from HBHuta Buczek; and (c) approx. PLN 7.2 million (plus recovery interests) had to be recovered from $\mathrm{BA}$.

36 Case T-440/07 Huta Buczek v Commission, application filed on 5 December 2007.

37 Case T-465/07 Salej and Technologie Buczek v Commission, application filed on 20 December 2007; case withdrawn and removed from register on 7 July 2010.

38 Case T-1/08 Buczek Automotive v Commission, application filed on 8 January 2008.

39 Case T-1/08 R Buczek Automotive v Commission, application filed on 8 January 2008 and Case T-440/07 R Huta Buczek v Commission, application filed on 5 December 2007.

40 Para. 27 of judgement of 14 March 2008 in Case T-1/08 R and para. 26 of judgement of 14 March 2008 in Case T-440/07 R.

${ }^{41}$ Paras 32-42 of judgement of 14 March 2008 in Case T-1/08 R. 
administrator of TB (HB's mother company) could support HB financially, and HB could also benefit from interim measures available in insolvency proceedings in national law. Second, even if HB would be forced to file for insolvency, Polish law foresees a possibility to continue business activity during insolvency proceedings. Finally, the applicant did not demonstrate that there were extraordinary circumstances that would outweigh public interest in safeguarding effective competition ${ }^{42}$.

BA's and HB's appeals on the merits are still pending before the GC.

As regards the recovery proceedings, to date, Poland has not achieved full recovery of the illegal aid (over a year after the deadline, Poland did not recover the illegal and incompatible aid from TB's subsidiaries despite the fact that the Commission decision places the main burden of the recovery on the subsidiaries). Therefore, the Commission concluded that the implementation of the Commission's recovery decision by Poland was not satisfactory and referred Poland to the Court of Justice (CJ) (formerly the European Court of Justice, ECJ) for failure to comply with the Buczek Decision ${ }^{43}$.

According to the Polish authorities, apart from obstacles of a purely technical nature, the reason for the significant delay in recovering the aid lies in the provisions of the Polish law on insolvency ${ }^{44}$. The Commission, however, took the view that it was not sufficient that Poland availed itself of all measures open to it. The application of those measures must result in the effective and immediate implementation of the Buczek Decision, as otherwise it would be necessary to assume that Poland has not complied with its obligations. Breach of the obligation of a Member State to recover aid arises when the steps taken by that Member State have had no influence on the actual recovery of a particular amount ${ }^{45}$.

The case illustrates that the Commission enforces the Treaty provisions on State aid not only by launching investigations and issuing negative State

42 Paras 64-65, 70 and 78 of judgement of 14 March 2008 in Case T-440/08 R.

43 Case C-331/09 Commission v Poland, application filed on 17 August 2009, OJ [2009] C 312/17.

44 OJ [2009] C 312/17. The Polish authorities explained that the State aid referred to in the Buczek Decision took the form of exemption for TB from its liabilities, even though its subsidiaries were the actual beneficiaries of the aid. In that situation TB was formally accountable for all liabilities, including the amounts to be recovered from HB and BA. The provisions of Polish law allegedly make it impossible for such claims to be written off, with the exception of cases involving 'complete impossibility'. In addition, if these claims are submitted, the official receiver dealing with the insolvency of TB is obliged to pay out the amounts owing, which may include the amounts to be recovered from the subsidiaries. Furthermore, if those amounts are recovered there will no longer be any legal basis on which recovery of those same amounts may be sought from $\mathrm{HB}$ and $\mathrm{BA}$.

45 OJ [2009] C 312/17. 
aid decisions but also by monitoring the actual recovery of illegal State aid continuously. In some cases, this may lead to action against a Member State that does not recover State aid from unlawful aid beneficiaries.

\section{Dell Poland (2009)}

In 2009, the European Commission adopted a guidance paper setting out criteria for the in-depth assessment of regional aid to large investment projects. The Regional Aid Guidelines 2007-2013 ${ }^{46}$ foresee that large investment projects above certain thresholds need to be individually notified to the Commission. For projects where the aid beneficiary has a market share of more than $25 \%$ or where the production capacity created by the project exceeds $5 \%$ of the EEA market (if the market concerned is considered as under-performing), the Commission has to open a formal investigation. Regional aid to such large investment projects may carry a greater risk of distorting competition and therefore requires a detailed compatibility assessment. The criteria for the in-depth assessment of regional aid to large investment projects ${ }^{47}$, which are based on the principles of the State Aid Action Plan ${ }^{48}$, and in particular the balancing test, detail how the Commission will evaluate the positive and negative effects of such aid. Member States are required to provide information on the project's contribution to regional development as well as the appropriateness, proportionality and incentive effect of the aid. Negative effects include the crowding-out of private investment or effects on trade such as displacement of investments.

The Dell Poland ${ }^{49}$ case was the first case where the Commission conducted the type of assessment referred to above.

Dell built a plant for the production of desktops, notebooks and servers which was expected to create up to 3,000 direct jobs in the Lódzkie region. The Łódzkie region was eligible for regional aid under Article 87(3)(a) of the EC Treaty (now Article 107 (3)(a) TFEU) as an area with an abnormally low standard of living and high unemployment. The investment costs taken into account for the calculation of the aid amounted to EUR 189.58 million. The manufacturing plant was opened in January 2008 and employed 1,700 workers in 2009.

\footnotetext{
46 Guidelines on national regional aid for 2007-2013, OJ [2006] C 54/13.

47 Communication from the Commission concerning the criteria for an in-depth assessment of regional aid to large investment projects, OJ [2009] C 223/3.

48 State Aid Action Plan - Less and better targeted State aid: a road map for State aid reform 2005-2009 of 7 June 2005, COM(2005) 107 final.

49 Dell Products Poland Sp.z o.o., a company wholly owned by Dell Inc. (US).
} 
Due to Dell's high market share as well as other uncertainties ${ }^{50}$, the Commission decided to open a formal investigation procedure into the intended regional aid of EUR 54.5 million to support Dell's investment. After a detailed economic analysis of the market and of the impact of the aid ${ }^{51}$, the Commission decided that Dell's project would significantly contribute to regional development and job creation in the disadvantaged region and that these benefits outweighed any potential negative effects on competition and loss of jobs elsewhere ${ }^{52}$. The Commission's investigation found that the aid provided an incentive for Dell to locate its manufacturing plant in Łódź by compensating for less favourable investment conditions in comparison with another envisaged location in Eastern Europe. The aid was limited to the amount necessary to compensate for the net additional costs of locating the plant in Łódź. Regarding the negative effects of the aid, the Commission found that the aid would not cause the crowding-out of competitors or the creation of significant production capacity in an underperforming market (desktops) since it had been demonstrated that the plant would have been built in any event, regardless of the aid, albeit in a different location. For the same reason, the Commission also concluded that job losses at other locations in the EU, such as those that would result from Dell's decision to close its manufacturing facility in Ireland, were not a consequence of the aid granted by the Polish authorities.

\section{Huta Częstochowa (Operator) (2009)}

As described in the 2008 issue of YARS, on 19 May 2005, the Commission opened a formal investigation ${ }^{53}$ into the restructuring process of Huta Częstochowa $(\mathrm{HCz})^{54}$ and, on 5 July 2005, adopted a mixed decision (hereafter, $\mathrm{HCz}$ Decision $)^{55}$. The $\mathrm{HCz}$ Decision held, inter alia, that around EUR 4 million of restructuring aid given to the company between 1997 and 2002

50 Other uncertainties included doubts about the market definition of the products made at the plant, the increase in production capacity generated by the project, the possible decline in the desktop market and Dell's market share for servers.

51 During the in-depth investigation, the Commission verified whether the thresholds of the regional aid guidelines were respected, whether the aid was necessary for the investment to take place in the assisted region, and whether the benefits of the measure outweigh the resulting distortion of competition. For this purpose, the Commission took into account information received from the Polish authorities and from interested parties, including two of Dell's competitors.

52 Commission Decision of 23 September 2009 in Case C 46/08 (ex N 775/07) on the aid which Poland is planning to implement for Dell Products (Poland) Sp. z o.o., OJ [2010] L 29/8.

53 OJ [2004] C 204/6.

54 Case C-20/2004 (ex NN/25/2004) - Restructuring aid to steel producer Huta Częstochowa.

55 OJ [2006] L 366/1. 
constituted aid incompatible with EU State aid rules, and thus, had to be returned. While the recovery concerned a period of time before accession (where the Commission normally has no jurisdiction), it was ordered under Protocol No. 8, which covers the time frame starting before and continuing after accession and clearly differs from other State aid provisions of the Treaty, such as the interim mechanism ${ }^{56}$. The Commission considered that Protocol No. 8 could be regarded as lex specialis that, with regard to its subject matter, would supersede any other provision of the Accession Act. HCz's purchaser, Donbass, $\mathrm{HCz}$ and other third parties ${ }^{57}$ appealed the $\mathrm{HCz}$ Decision. On 11 December 2006, the GC dismissed HCz's application for interim measures.

On 1 July 2009, the GC issued a judgement partially annulling the $\mathrm{HCz}$ Decision in so far as it concerned Operator ARP sp. z o.o. (Operator) ${ }^{58}$. The Court held that the Commission had found Operator erroneously to be an entity jointly and severally liable to repay the aid in question. Where negative decisions are taken in cases of unlawful aid, the Commission is required to decide that the Member State concerned is to take all necessary measures to recover the aid from the 'beneficiary' 59 . The term 'beneficiary' does not designate solely the original beneficiary of the aid but, where appropriate, any undertaking to which assets have been transferred in order to render the provisions of its recovery order inoperative ${ }^{60}$. However, in the case of Operator, on the date on which the $\mathrm{HCz}$ Decision was adopted, no assets had been transferred to the applicant ${ }^{61}$. Moreover, the widening of the group of entities required to repay the aid can only be justified if the transfer of assets leads to the risk of circumvention of the effects of the recovery order, in particular if the original beneficiary is left

56 See Kuik K., 'State Aid and the 2004 Accession - Overview of Recent Developments' (2004) 3(3) European State Aid Law Quarterly.

57 Case T-288/06. Case 291/06 and Case 297/06, respectively.

58 Operator was created during the restructuring of $\mathrm{HCz}$ which took place between 2002 and 2005. In 2002, Huta Stali Częstochowa sp. z o.o. (HSCz), ultimately controlled by the Polish Treasury, was formed to continue HCz's steel production. In 2004, the two holding companies, wholly owned by $\mathrm{HCz}$, were formed and received HCz's steel assets and certain other assets necessary for production. Assets not linked to production (non-steel assets) and the electricity company Elsen were transferred to Operator, a company answerable to Agencja Rozwoju Przemysłu S.A. (the Polish Industrial Development Agency, owned by the Polish Treasury) (ARP), to settle public-law claims subject to restructuring (taxes and social security contributions).

59 Article 14(1) of Regulation No. 659/1999.

60 Commission Decision 1999/720/EC, ECSC of 8 July 1999 on State aid granted by Germany to Gröditzer Stahlwerke GmbH and its subsidiary Walzwerk Burg GmbH (OJ [1999] L 292/27).

61 Although the $\mathrm{HCz}$ restructuring operation contemplated that assets would be transferred to 'operator', Operator gave its agreement to exercising such function in the $\mathrm{HCz}$ restructuring procedure only several days after the decision had been adopted. 
like an 'empty shell'62. That widening may also be justified by the fact that the acquirer(s) retain(s) the actual benefit of the competitive advantage connected with the receipt of the aid granted ${ }^{63}$.

No advantage in relation to other market operators results from the asset purchase where assets are bought at the market price ${ }^{64}$. For the purposes of checking the financial conditions of a transfer, the national authorities may take into consideration, in particular, any expert's report prepared at the time of the transfer ${ }^{65}$. In Operator's case, an independent expert's report assessed the market value of the assets received at PLN 156 million. In contrast, the total value of the public-law obligations assumed legally amounted to more than PLN 280 million, i.e. they exceeded significantly the market value of the assets transferred to Operator.

The GC also noted that, given that Operator was neither a company belonging to the vendor's group nor present on the steel production market (it fulfilled the role of a buyer of debts and assets of undertakings in difficulty to, in return, satisfy their creditors), the Commission should have demonstrated more specifically a risk of circumvention and actual benefit to Operator of a competitive advantage related to the receipt of the aid in question ${ }^{66}$.

The Court held that the Commission erred in including Operator in the group of entities jointly and severally liable to repay the aid in question and, consequently, annulled the $\mathrm{HCz}$ Decision in so far as it concerned Operator.

\section{Mergers}

The years 2008 and 2009 have marked some gradual changes in EU merger control ${ }^{67}$. Despite the economic and financial downturn, there were several cases of consolidation, notably in the pharmaceutical and airline sectors, that affected Poland. That said, it is also noteworthy that unlike in other countries,

62 Case T-324/00 CDA Datenträger Albrechts v Commission [2005] ECR II 4309, para. 98 et seq.

63 Case C-277/00 Germany v Commission [2004] ECR I-3925 (SMI), para. 86.

${ }^{64}$ Para. 67 of of judgement in Case T-291/06. In the case of the takeover of assets, since the purchaser has paid a purchase price in line with the market for the takeover of assets, the purchaser does not retain the actual benefit of the competitive advantage connected with the receipt of the aid granted to the vendor. In such a case, it cannot be found that the original beneficiary of the aid is left like an 'empty shell' or that the purchaser has retained the actual benefit of the aid (CDA Datenträger Albrechts, para. 99).

65 Case C-214/07 Commission v France [2008] ECR I-0000, para. 59 and 60.

66 Para. 69 of judgement in Case T-291/06.

67 See G. Drauz, T. Chellingsworth, N. Hyrkas, 'Recent Developments in EC Merger Control' (2010) 1(1) Journal of European Competition Law and Practice 12-26. 
the financial crises did not lead to rescue mergers or nationalisation of banks in Poland.

The Commission's policy with respect to remedies has continued to be scrupulous with the Commission's preference for structural remedies, such as divestitures. In order to provide improved guidance on questions related to remedies, in October 2008, the Commission adopted a new Notice on Remedies $^{68}$, which codifies recent practice of the European Union Courts and the European Commission and provides a number of clarifications.

\section{Teva / BarrPharmaceuticals (2008)}

On 19 December 2008, the Commission approved the proposed acquisition of Barr Pharmaceuticals (United States) by Teva Pharmaceutical Industries (Israel), subject to conditions ${ }^{69}$. The merger was cleared after Teva submitted commitments in a number of national markets for pharmaceutical products ${ }^{70}$ to offset the Commission's competition concerns that had arisen in the Phase I investigation.

Both merging parties primarily engaged in production and marketing of generic medicines. Teva was the largest generics producer in the world. Within the EEA, the parties had overlapping activities in 11 countries (including Poland).

In terms of the product market definition, for several medicines, the Commission departed from its traditional starting point of defining the relevant product markets according to the therapeutic indication (i.e. intended use) pursuant to the third level of the Anatomical Therapeutic Chemical classification (ATC3). Following the results of the market investigation, the Commission analysed some markets at the molecular level ${ }^{71}$ under the assumption that medicines based on the same molecule are each other's closest competitors (regardless of whether they are originator medicines or their generic copies). In line with previous decisions, the Commission considered the relevant markets to be national in geographic scope.

As regards the relevant markets in Poland, the Commission identified competition concerns regarding two cancer medicines (based on paclitaxel and on calcium folinate) where the parties combined market share would amount to $60-70 \%$, and prescription vitamin products (riboflavin and pyridoxine), where

68 Commission Notice on remedies acceptable under the Council Regulation (EC) No. 139/2004 and under Commission Regulation (EC) No. 802/2004, OJ [2008] C 267/1.

${ }^{69}$ Case No. COMP/M.5295 - Teva/Barr Pharmaceuticals.

70 In total, 15 cancer medicines in the Czech Republic, Hungary, Poland, the Slovak Republic and Slovenia, as well as two other medicines in Poland.

71 A molecule is the most active pharmaceutical ingredient. 
their combined market share would be $90-100 \%$. The Commission concluded that barriers to entry were significant for generic drugs given that entry required significant investments to obtain market authorisations and there were lengthy development and administrative procedures. For oncology drugs specifically, entry was additionally hampered by the medicines' hazardous (cytostatic) nature which lead to special production and handling requirements. The proposed remedy consisted in the divestment of the relevant Teva businesses, thus removing the entire overlap between the merging parties.

\section{Pfizer / Wyeth (2009)}

On 17 July 2009, the Commission approved another proposed acquisition in the pharmaceuticals sector, namely of the pharmaceutical and health care products company Wyeth (United States) by the global pharmaceutical company Pfizer (United States) ${ }^{72}$. The approval was conditional upon Pfizer's commitment to divest several types of animal health vaccines, pharmaceuticals and medicinal feed additives in the EEA or in specific Member States, whereas the transaction was not considered problematic in human health pharmaceuticals where the companies' activities were to a large extent complementary.

With respect to product market definition, the Commission divided the animal health market into three main categories: (i) biologicals (vaccines), (ii) pharmaceuticals and (iii) medicinal feed additives. The markets were considered to be national in scope for similar reasons as described above for human health pharmaceuticals. Competition concerns in the Polish markets were found in relation to vaccines for prevention of respiratory infection in swine (mycoplasma hyopneumoniae vaccines), where the parties' combined market share would be $30-40 \%$. The Commission found that, despite the presence of two other competitors, the segment is subject to very high entry barriers. It is highly concentrated and dominated by a few well-established multinational players. The market is mature and has been stable in the last three years with no changes expected.

To address the Commission's competition concerns, Pfizer proposed to divest a number of specific products for each of the markets where competition concerns had been identified, i.e. several national markets in the vaccine and pharmaceutical area and in one medicinal feed additives area. Pfizer also offered to divest Wyeth's vaccines manufacturing facility in Sligo, Ireland, because the existing production capacity is scarce and building new capacity is a lengthy and complex process.

72 Case No. COMP/M. 5476 - Pfizer / Wyeth. 


\section{Aviva / Bank Zachodni (2008)}

The Aviva / Bank Zachodni case ${ }^{73}$ concerned a creation of two new fullfunction joint ventures ${ }^{74}$ in the insurance sector in Poland by the UK's Aviva insurance group and the Polish Bank Zachodni WBK S.A. The first joint venture, BZ WBK - CU Towarzystwo Ubezpieczeń na Życie S.A., would be active in underwriting life insurance for mortgage borrowers and investment products, whereas the second joint venture, BZ WBK - CU Towarzystwo Ubezpieczen Ogolnych S.A., would underwrite general insurances, such as card theft, cover for unemployment, home contents and civil liability ${ }^{75}$. The Commission approved this concentration unconditionally in Phase I on 5 February 2008.

Aviva is an international insurance group that is also active in long term savings and fund management. Bank Zachodni WBK S.A. is a universal bank, offering services to personal customers, small and medium enterprises, large corporate companies, as well as a wide range of services such as mutual funds, brokerage activities, factoring and asset management. In the relevant period of time, it was controlled by the Allied Irish Banks group.

The Commission's investigation focused on insurance products in the Polish market, where the two joint ventures would exclusively be active and on a possible vertical relationship as regards the market for asset and pension fund management, where both parent companies are active. The Commission's investigation indicated that in line with previous Commission decisions, the Polish insurance market should be divided into non-life insurance, life insurance and reinsurance with possibly further distinction between different types of insurances belonging to each of these three broad segments. Asset management and pension funds were each considered to be a separate market, distinct from life and non-life insurance. In terms of geographic market definition, insurance pension funds markets in Poland have been regarded as mainly national in scope due to, inter alia, differing regulatory systems and fiscal constraints, but some product markets within the life insurance segment (such as saving and investment products) could, according to the Commission market investigation, be wider in scope. The market investigation provided evidence for the asset management being global in scope.

The Commission's market investigation did not indicate any horizontal or vertical competition concerns resulting from the planned transaction. It also did not provide any indications pointing towards coordinated effects in

\footnotetext{
73 Case No. COMP/M.4950 - Aviva/Bank Zachodni.

74 For a discussion on the concept of full-functionality, see the Consolidated Jurisdictional Notice, OJ [2008] C 95/23 et seq.

75 The Polish law requires life insurance to be run separately from non-life insurance.
} 
the meaning of Article 2(4) of Regulation 139/2004. As regards horizontal overlaps, the parties' combined market share was below $15 \%$ with an increment below 5\%. Regarding the vertically related market for asset and pension fund management, Aviva and Bank Zachodni would have combined market shares between $20 \%$ and $30 \%$, which as such was considered to be unlikely to lead to input or customer foreclosure ${ }^{76}$.

\section{Consolidation in the European airline industry (2009)}

The year 2009 was marked by a wave of mergers in the European airline industry 77 . The Commission reviewed a number of cases, namely Iberia/ Vueling/Clickair ${ }^{78}$, Lufthansa/bmi ${ }^{79}$, Lufthansa/SNAH (Brussels Airlines) ${ }^{80}$ and Lufthansa/Austrian Airlines ${ }^{81}$. The merging parties provided air transport services, inter alia, on routes connecting Polish airports to other European hubs, however the competition concerns identified by the Commission on a number of short-haul routes did not relate to routes originating or destined in Poland.

It could be noted for the future that the Commission has modified its traditional approach to mergers in the airline industry according to which in earlier cases the Commission had analysed not only overlaps between the merging parties but also overlaps between one party and the other party's alliance partner. In the latest cases, the Commission decided to restrict its analysis to overlaps between the merging parties and to consider other markets to be affected only if there is solid evidence that the cooperation between one merging party and a third party (its alliance partner) will be extended to the other merging party ${ }^{82}$. This had a bearing on overlaps between Lufthansa's Star Alliance partners (such as LOT Polish Airlines) on the one hand, and Brussels Airlines or Austrian Airlines on the other hand. In principle, such overlaps were not considered as reportable markets. In addition, as the result of the change in its approach, the Commission did not aggregate LOT's market share

76 Guidelines on the assessment of non-horizontal mergers, OJ [2008] C 265/07, para. 25.

77 See L. Bonova, D. Koska, A. Specker, 'Consolidation of the EU airline industry: How the Commission kept seatbelts fastened in the 2009 airline merger wave' (2009) 3 Competition Policy Newsletter.

78 Case No. M.5364 - Iberia/Vueling/Clickair, OJ [2009] C 72/23.

79 Case No. M.5403 - Lufthansa/bmi, OJ [2009] C 158/1.

${ }^{80}$ Case No. M.5335 - Lufthansa/SNAH (Brussels Airlines), OJ [2009] C 295/11.

81 Case No. M.5440 - Lufthansa/Austrian Airlines, OJ [2010] C 16/11.

82 In other words, a market is considered as affected only if there is evidence that one party will be integrated into the other party's partnership with another airline on this market, or that competition will otherwise be reduced as a result or as a foreseeable consequence of the merger. 
with that of Lufthansa's on overlap routes between the respective merging parties but considered LOT as a fully-fledged competitor.

\section{Electronic communications - regulatory framework}

\subsection{Progress Report 2009}

According to the European Commission's Progress Report on the Single European Electronic Communications Market 200983, Europe's e-communications are still fragmented along national borders due to inconsistent implementation of existing EU regulation by national regulators.

Analysing the regulatory developments, the Commission has referred to Poland in the context of three issues: the national regulatory authority's (NRA) independence, the market analysis necessary to impose regulatory measures and broadband.

\section{Independence of NRAs}

Independent NRAs are a prerequisite for ensuring fair and effective regulation of the sector. The conditions for the appointment or removal of the head of the Polish NRA led the Commission to refer Poland to the CJ and to launch an infringement proceeding against Romania. The Commission has also been examining the conditions under which the head of the Slovakian NRA was dismissed.

\section{Market analysis by NRAs}

The Commission noted in the report that significant progress had been made with the second round of market analyses. In some cases, the third round has already started (e.g. Finland, Austria and Hungary). While following some recent notifications, almost all Member States have completed the first round of market analyses; this was not the case for Poland, Bulgaria and Romania.

83 Communication of 25 May 2010 from the Commission to the European Parliament, The Council, the European Economic and Social Committee and the Committee of the Regions, Progress Report on the Single European Electronic Communications Market 2009 (15th Report), COM(2010)253 final. 


\section{Broadband price controls}

The Commission noted that the approaches to setting price control obligations for wholesale broadband access varied significantly across Member States. Some NRAs rely on "retail minus" methodologies while others apply cost-orientation. Some NRAs, e.g. the Polish UKE, have not been able to implement the cost orientation obligations which they have imposed and rely in the meantime on other methods such as benchmarking.

\subsection{Judgments in regulatory infringement cases}

\section{Access Directive - interconnection negotiation obligation $(2008)^{84}$}

The Access Directive ${ }^{85}$ is part of the 'Electronic Communications Package' which, with four other directives, aims at making the communications networks and services sector more competitive. The Access Directive applies to all forms of communication networks carrying publicly available communications services ${ }^{86}$. It establishes rights and obligations for operators $^{87}$ and for undertakings seeking interconnection ${ }^{88}$ and/or access ${ }^{89}$ to their networks. Its objective is to establish a framework, which will encourage competition by stimulating the development of communications services and networks, and also to ensure that any bottlenecks in the market do not constrain the emergence of innovative services that could benefit users. However, insofar as there is no effective competition on the market, the NRAs must act, including by imposing obligations on operators with significant market power.

The Access Directive establishes a fundamental rule regarding interconnection to the effect that all network operators have rights and obligations as regards

84 Judgement of the Court of Justice of 13 November 2008, C-227/07 Commission v Poland, OJ [2009] C 6/5.

85 Directive 2002/19/EC of the European Parliament and of the Council of 7 March 2002 on access to, and interconnection of, electronic communications networks and associated facilities (Access Directive), OJ [2002] L 108/7.

86 These include fixed and mobile telecommunications networks, networks used for terrestrial broadcasting, cable TV networks, and satellite and Internet networks used for voice, fax, data and image transmission.

87 The term 'operator' is defined by the Directive as an undertaking providing a public communications network or an associated facility.

88 The term 'interconnection' is defined by the directive as the physical and logical linking of public communications networks in order to allow the users of one undertaking to communicate with users of the same or another undertaking, or to access services provided by another undertaking.

89 The term 'access' means the making available of facilities and/or services to another undertaking for the purpose of providing electronic communications services. 
interconnection agreements, namely to negotiate interconnection with each other for the purpose of providing publicly available electronic communications services. Additionally, the Directive imposes obligations on NRAs. They are responsible for carrying out regular market analyses to determine whether one or more operators have significant power on the market in question. Where, following a market analysis, an operator is identified as having significant power on a given market, the NRA will impose, inter alia, obligations of access to, and use of, specific network facilities, such as to negotiate in good faith with undertakings requesting access.

Member States were obliged to transpose the Access Directive into national laws by 24 July 2003. In 2005, the Commission informed Poland that it had concerns regarding the transposition of the Directive and after issuing a reasoned opinion to that effect in 2006, it initiated an infringement procedure under Article 226 EC (now Article 258 TFEU) before the ECJ (now the CJ) in May 2007.

The Commission believed that the Polish Law on telecommunications, in particular Article 26, had not been in line with Articles 4(1) and 5(1) of the Access Directive. Whereas the Access Directive provides for the NRA to be empowered to impose an obligation to negotiate access agreements only following a market analysis and only towards operators of telecommunications networks with significant market power, the Polish law imposes such an obligation without prior evaluation of the degree of effective competition on the market concerned. Moreover, the Commission criticised the wide powers of intervention set out in Articles 26-30 of the Polish law as it considered that NRAs should be empowered to act only in certain specified cases.

The CJ held that the Polish law imposes a general obligation to negotiate agreements for access to the telecommunications network and agreed with the Commission that the law therefore did not allow for any assessment of circumstances, such as the level of competition, which is required under the Access Directive. Therefore, the Court decided that Article 4(1) has not been properly transposed. The Court however did not agree with the Commission's second plea, pointing out that Article 5(1) provides for a general power for the NRA for the purpose of achieving the objectives of the Access Directive and the Commission failed to demonstrate that the relevant provisions of the Polish law do not achieve these objectives.

The CJ followed the same principles in interpreting Articles 4 and 5 of the Access Directive for the purposes of TeliaSonera $v i M E Z^{90}$.

90 Judgment of the Court of Justice of 12 November 2009, C-192/08 TeliaSonera Finland Oyj v iMEZ Ab, OJ [2010] C 11/04. 


\section{Framework Directive - subscriber definition ${ }^{91}$ (2009)}

The Framework Directive ${ }^{92}$ forms also part of the Electronic Communications Package mentioned above. It contains a definition of a subscriber. In 2005, the Commission launched infringement proceedings against Poland for the incorrect transposition of the Framework Directive into national law ${ }^{93}$. The Commission considered that the definition of a 'subscriber' in the Polish law is not in line with the definition set out in the Framework Directive. Pursuant to Article 2 of the Framework Directive, a 'subscriber' means any natural person or legal entity who or which is party to a contract with the provider of publicly available electronic communications services for the supply of such services. The Polish Law on telecommunications defines a subscriber as a legal entity, which was party to a written contract with such a provider. In the Commission's view such a narrower definition deprived subscribers, who did not enter into a written contract, of certain rights resulting from the telecoms directives.

The CJ agreed with the Commission and held that although Member States were not obliged to transpose directives literally into national laws, it had been incumbent on Poland to refute evidence presented in this case by the Commission. Poland failed to demonstrate that, despite the difference in definition, the provisions of the Polish law on telecommunications achieved the objectives of the electronic communications directives.

A point of note relates to the Court's position on the burden of proof in infringement proceedings. The $\mathrm{CJ}$ reaffirmed that when the Commission provides sufficient evidence to suggest that the national provisions adopted by the defendant Member State do not ensure the effective implementation of the Directive, that Member State has the burden of proof to challenge these findings and the resulting consequences.

91 Judgement of the Court of Justice of 22 January 2009, C-492/07, Commission v Poland, OJ [2009] C 69/14.

92 Directive 2002/21/EC of the European Parliament and of the Council of 7 March 2002 on a common regulatory framework for electronic communications networks and services (Framework Directive), OJ [2002] L 108/33.

93 See EUROPA press release MEMO/05/478; the deadline for implementation expired on 30 April 2004. 


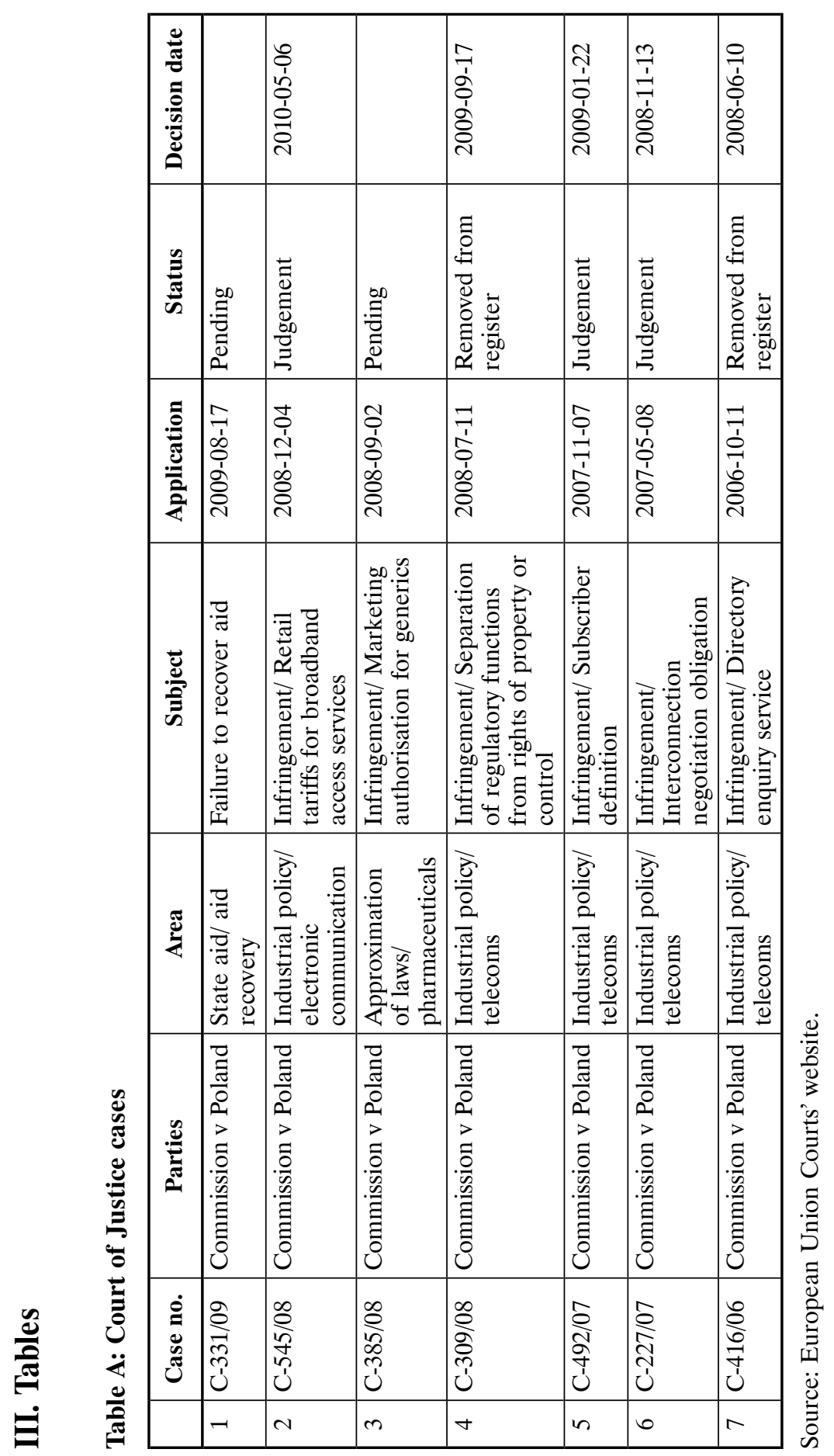




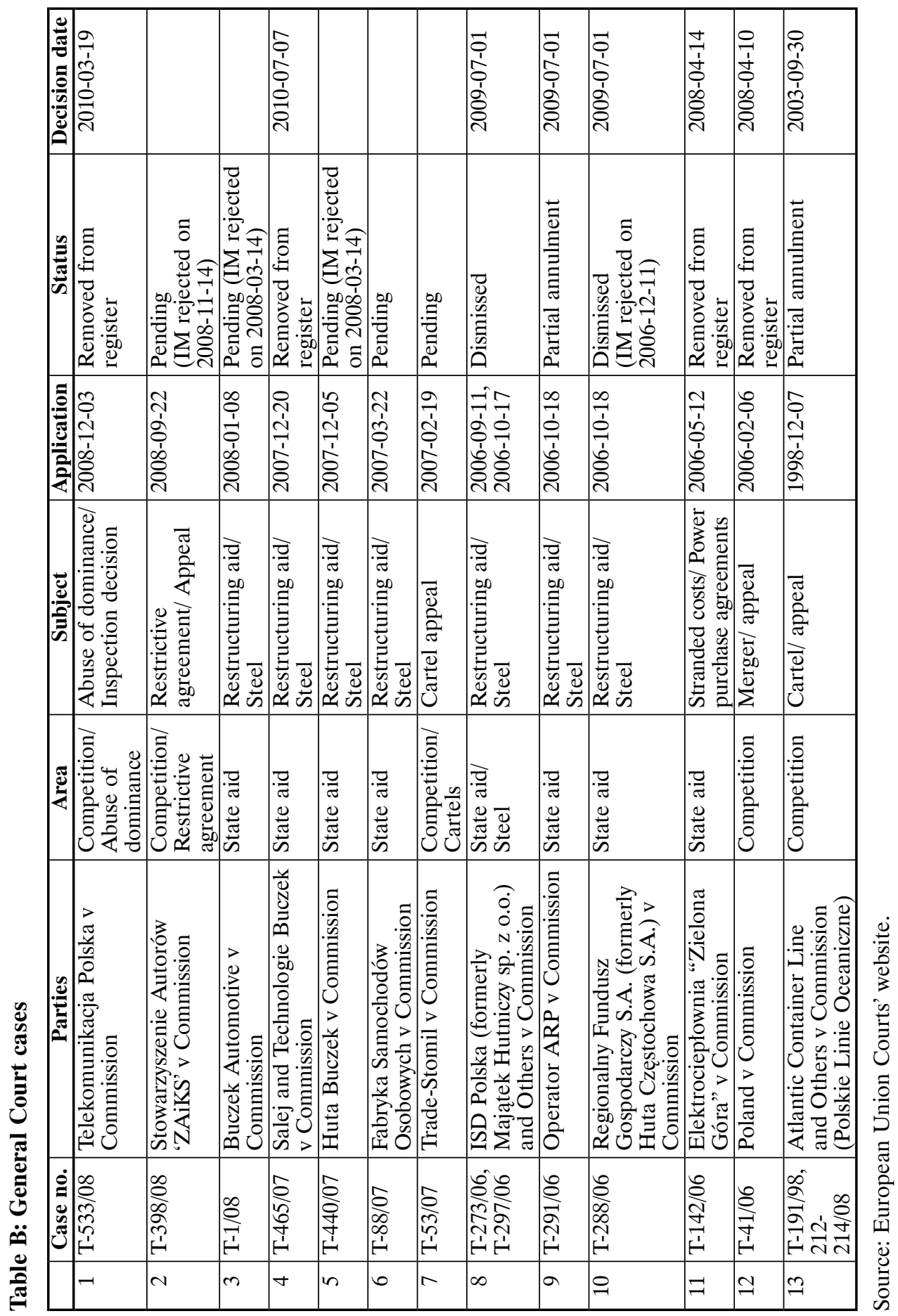




\begin{tabular}{|c|c|c|c|c|c|c|c|c|c|c|c|}
\hline 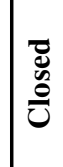 & 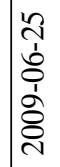 & 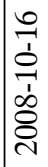 & 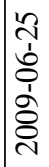 & 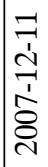 & 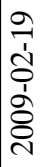 & 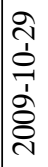 & 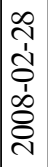 & 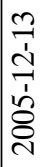 & 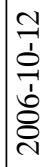 & 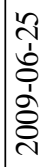 & 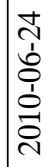 \\
\hline
\end{tabular}

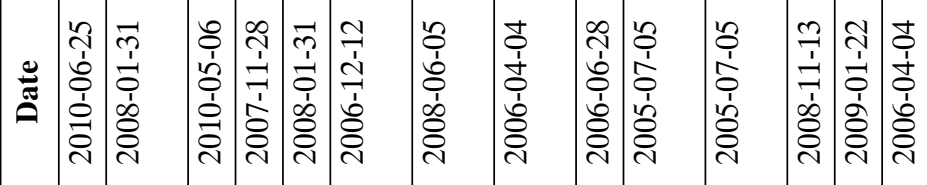

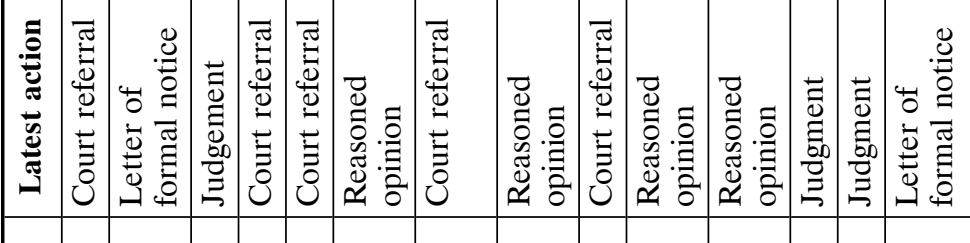

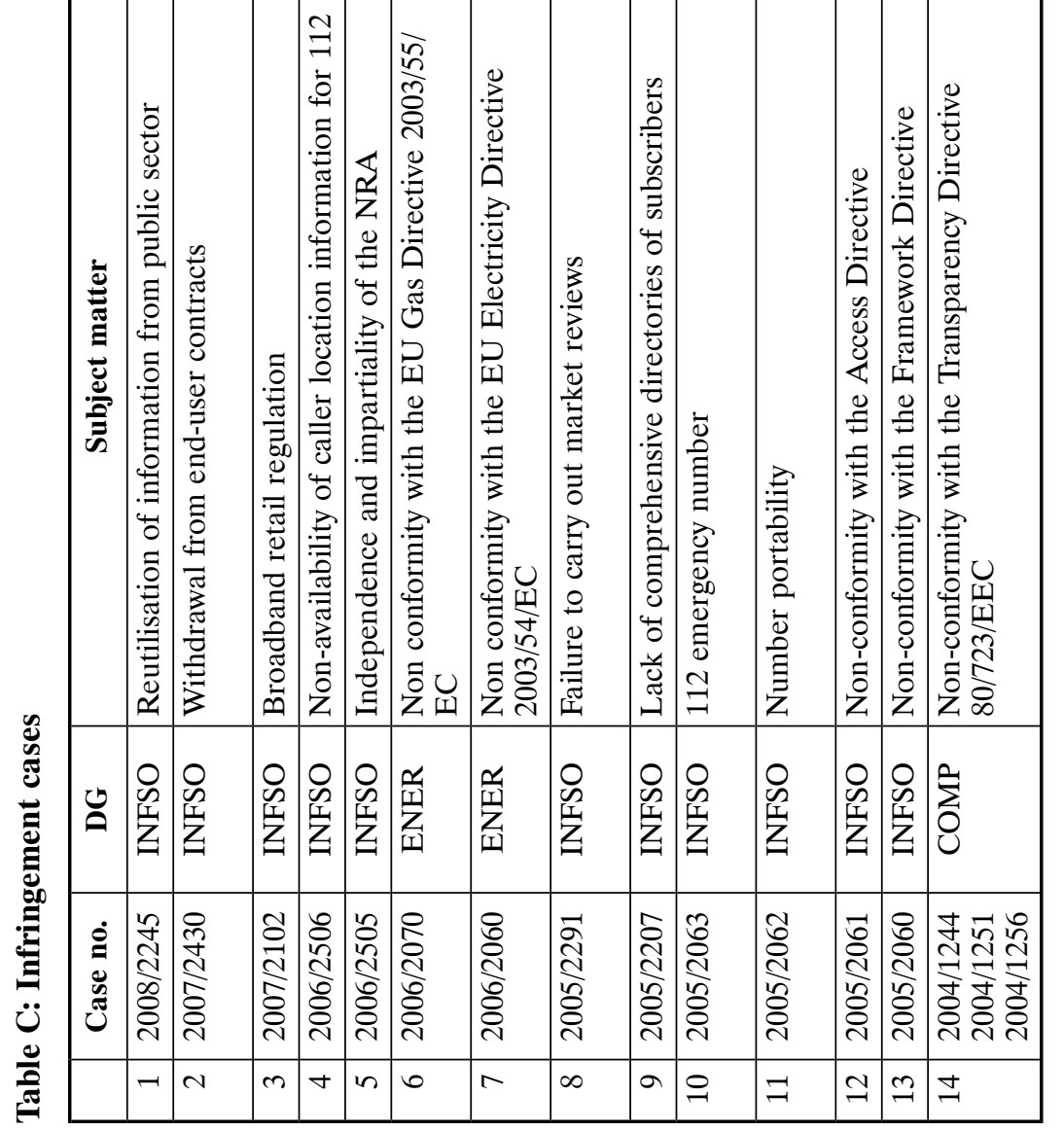

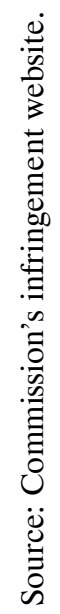




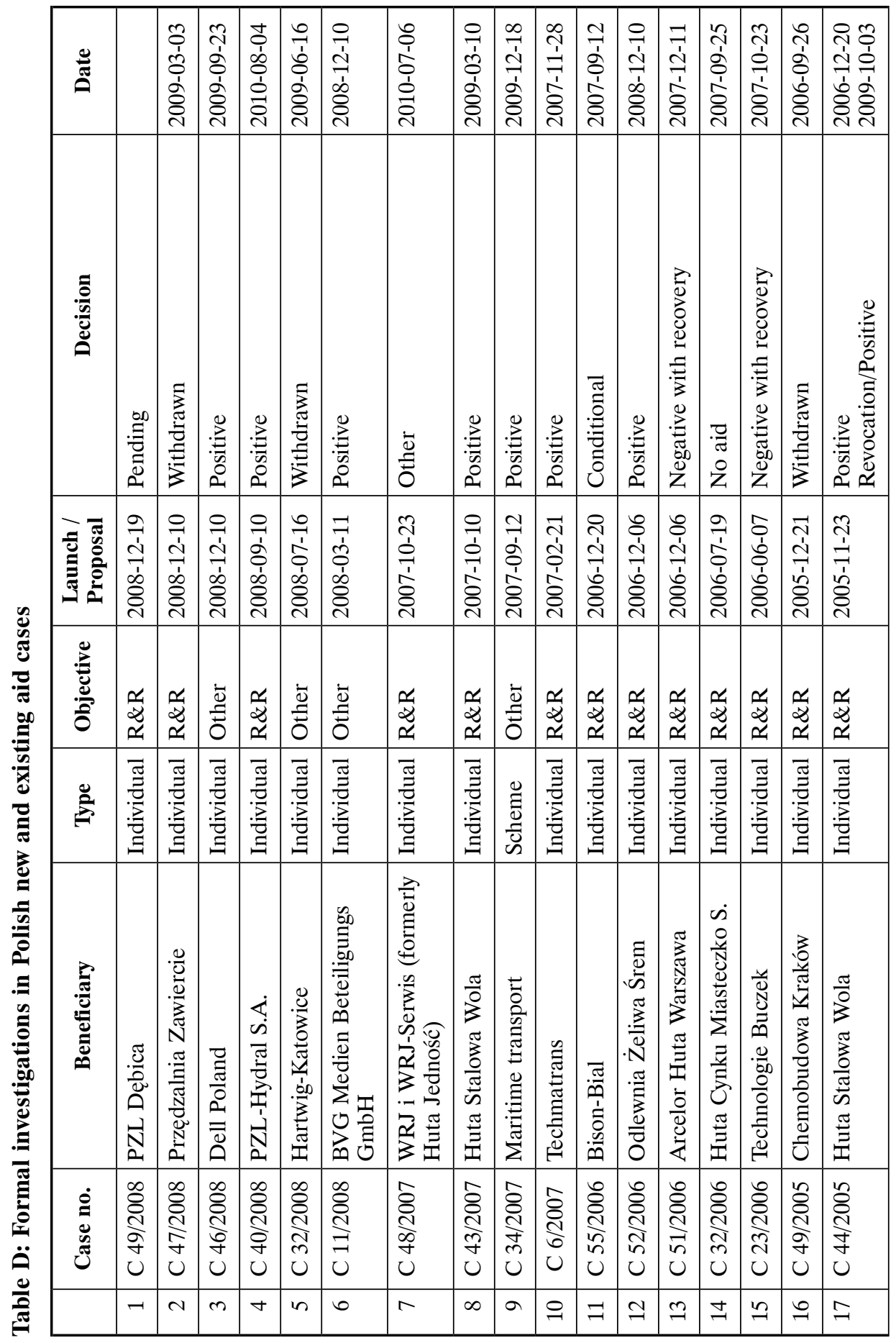




\begin{tabular}{|c|c|c|c|c|c|c|c|c|c|}
\hline 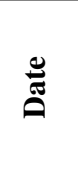 & 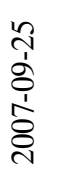 & 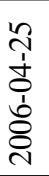 & 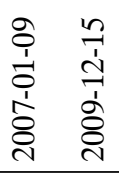 & 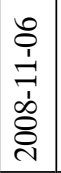 & 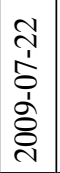 & 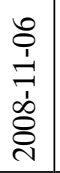 & 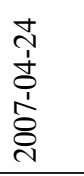 & 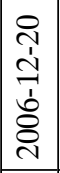 & 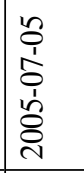 \\
\hline .气̃ & 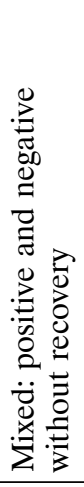 & 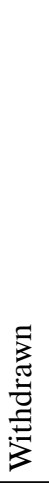 & 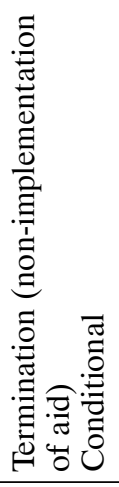 & 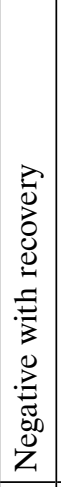 & $\begin{array}{l}0 \\
: \\
0 \\
0 \\
0 \\
\end{array}$ & $\begin{array}{l}z \\
0 \\
0 \\
0 \\
0 \\
0 \\
\Xi \\
3 \\
3 \\
0 \\
0 \\
0 \\
0 \\
0 \\
0 \\
Z \\
Z\end{array}$ & 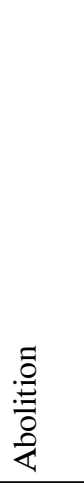 & 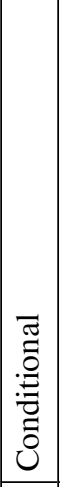 & 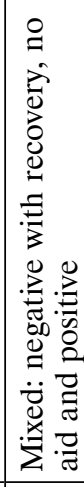 \\
\hline 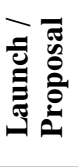 & 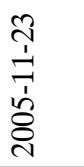 & 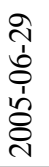 & 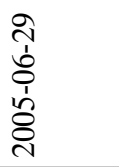 & 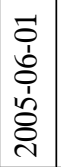 & 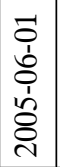 & 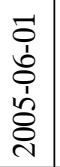 & 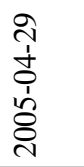 & 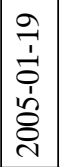 & 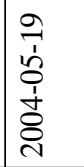 \\
\hline 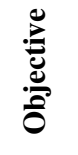 & $\stackrel{\bar{D}}{\stackrel{ \pm}{0}}$ & $\begin{array}{l}\bar{D} \\
\stackrel{\overrightarrow{0}}{0}\end{array}$ & $\frac{\bar{D}}{\stackrel{ \pm}{0}}$ & $\begin{array}{l}\alpha \\
\tilde{z} \\
\alpha\end{array}$ & $\begin{array}{l}\mathscr{\alpha} \\
\tilde{z} \\
\mathscr{\alpha}\end{array}$ & 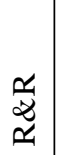 & $\frac{\bar{d}}{\stackrel{ \pm}{0}}$ & $\begin{array}{l}\alpha \\
z \\
\alpha \\
\alpha\end{array}$ & $\mid \begin{array}{l}\frac{\alpha}{2} \\
\not{x}\end{array}$ \\
\hline$\stackrel{\Xi}{ٍ ~}$ & 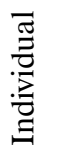 & 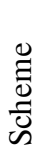 & 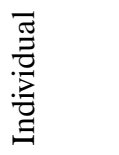 & 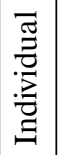 & 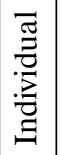 & 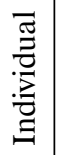 & 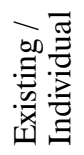 & 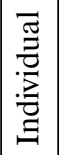 & 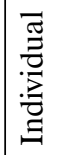 \\
\hline ف률 & 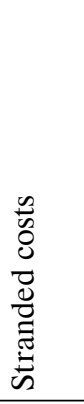 & $\begin{array}{l}\frac{\pi}{4} \\
\frac{\pi}{0} \\
0 \\
2 \\
\frac{\pi}{N} \\
0 \\
0 \\
2\end{array}$ & $\begin{array}{l}\frac{\pi}{4} \\
\frac{\pi}{0} \\
0 \\
0 \\
\tilde{\pi} \\
0 \\
0 \\
\end{array}$ & 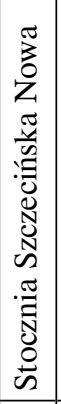 & 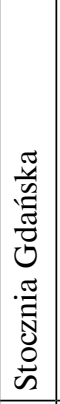 & 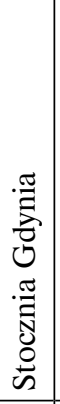 & $\begin{array}{l}\frac{\pi}{4} \\
\frac{\pi}{0} \\
0 \\
0 \\
\frac{\pi}{0} \\
0 \\
0\end{array}$ & $\begin{array}{c}0 \\
0 \\
5 \\
\text { II } \\
0 \\
8 \\
0 \\
0 \\
0 \\
\tilde{J} \\
0 \\
\end{array}$ & 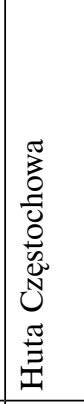 \\
\hline \multirow[t]{2}{*}{$\begin{array}{l}\dot{\Xi} \\
\vdots \\
\tilde{\Xi} \\
\tilde{\Xi}\end{array}$} & 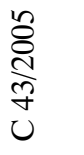 & 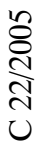 & 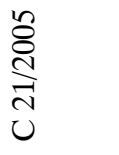 & 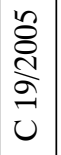 & 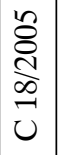 & 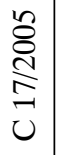 & 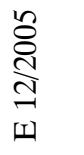 & 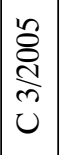 & 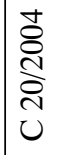 \\
\hline & $\infty$ & $\stackrel{2}{2}$ & ๙ิ & $\vec{\sim}$ & $\widetilde{N}$ & $\ddot{\sim}$ & さ & $\stackrel{n}{\sim}$ & ㄴ. \\
\hline
\end{tabular}




\begin{tabular}{|c|c|c|c|c|c|c|c|c|c|c|c|c|c|c|c|}
\hline ڤี๊ & & 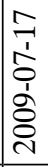 & 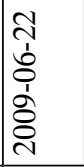 & 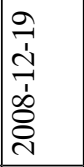 & 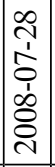 & 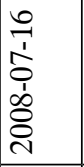 & 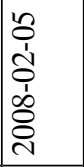 & 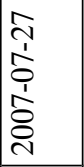 & 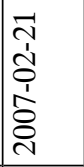 & 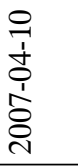 & 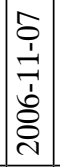 & 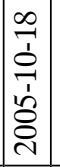 & 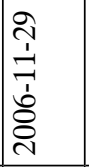 & 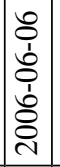 & 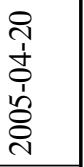 \\
\hline 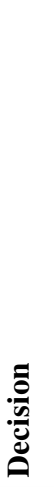 & 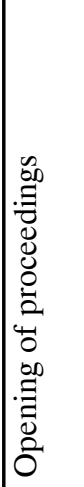 & 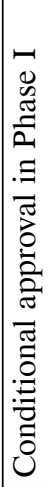 & 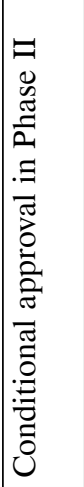 & 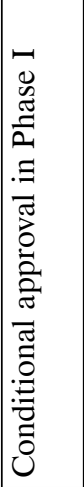 & 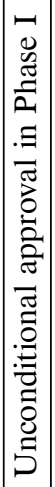 & 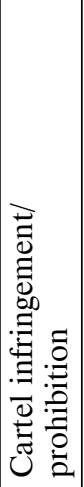 & 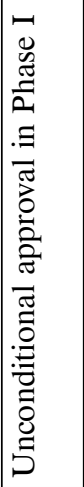 & 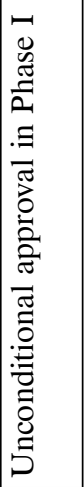 & 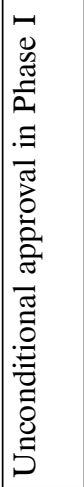 & 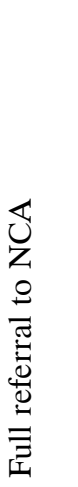 & 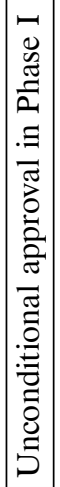 & 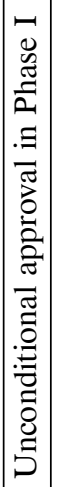 & 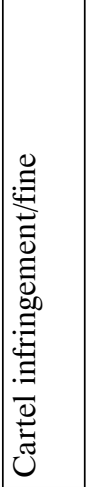 & 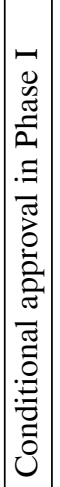 & 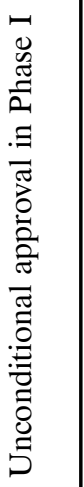 \\
\hline 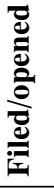 & 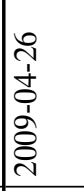 & 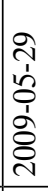 & 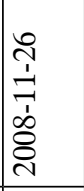 & 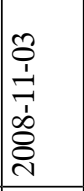 & 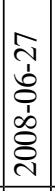 & 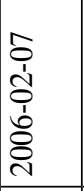 & 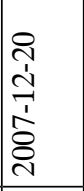 & 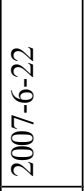 & $\begin{array}{l}\frac{1}{1} \\
\frac{1}{1} \\
\hat{8} \\
8 \\
\text { i }\end{array}$ & 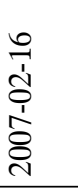 & 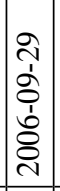 & 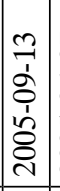 & 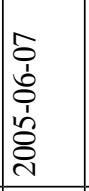 & 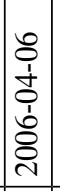 & 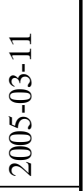 \\
\hline 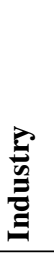 & 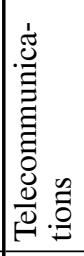 & 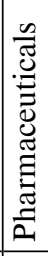 & 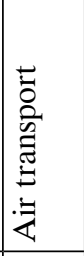 & 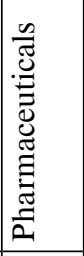 & $\begin{array}{c}\bar{\Xi} \\
\tilde{\Xi} \\
\tilde{\simeq}\end{array} \mid$ & 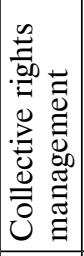 & 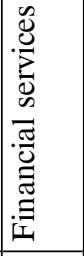 & 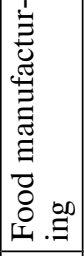 & 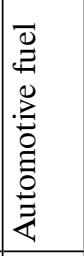 & 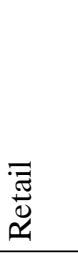 & 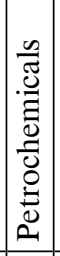 & 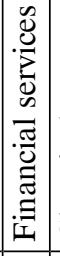 & 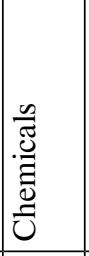 & 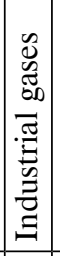 & 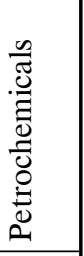 \\
\hline$\stackrel{\Perp}{ٍ}$ & 营 & 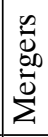 & 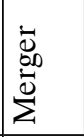 & 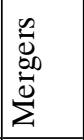 & $\begin{array}{c}\dot{\bar{s}} \\
\dot{\omega} \\
\overrightarrow{\mathrm{s}} \\
\end{array}$ & 泀 & $\begin{array}{l}\overrightarrow{\vec{d}} \\
\dot{s} \\
\overrightarrow{\vec{s}} \\
\Sigma\end{array}$ & $\begin{array}{l}\overline{\vec{D}} \\
\dot{\vec{b}} \\
\stackrel{\vec{\Sigma}}{\Sigma}\end{array}$ & 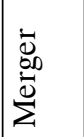 & $\begin{array}{l}\vec{\Delta} \\
\vec{D} \\
\overrightarrow{0} \\
\stackrel{\Sigma}{\Sigma}\end{array}$ & $\left|\begin{array}{l}\dot{\bar{D}} \\
\dot{0} \\
\overrightarrow{\bar{s}}\end{array}\right|$ & 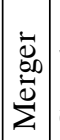 & 亗 & $\mid \begin{array}{l}\overline{\vec{d}} \\
\bar{s} \\
\dot{\vec{c}}\end{array}$ & $\begin{array}{l}\overline{\bar{\Delta}} \\
\dot{\omega} \\
\dot{\vec{\omega}}\end{array}$ \\
\hline 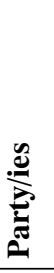 & 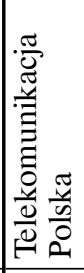 & 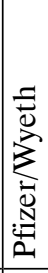 & 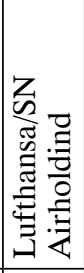 & 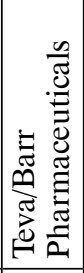 & 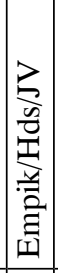 & 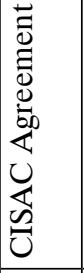 & 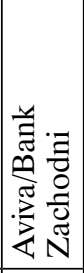 & 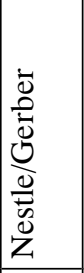 & 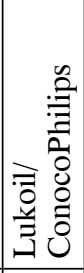 & 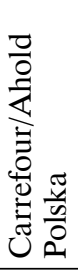 & 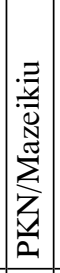 & 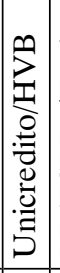 & 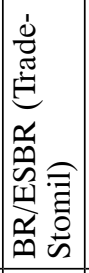 & 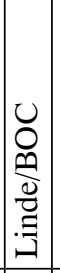 & 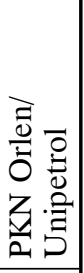 \\
\hline 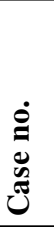 & 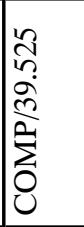 & 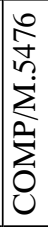 & 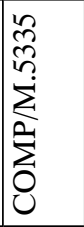 & 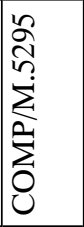 & 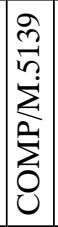 & $\mid \begin{array}{l}\infty \\
0 \\
0 \\
\infty \\
0 \\
0 \\
\vdots \\
0 \\
0 \\
0\end{array}$ & 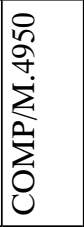 & 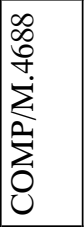 & 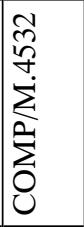 & 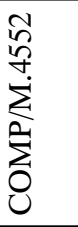 & 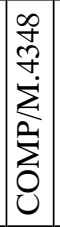 & 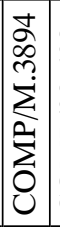 & 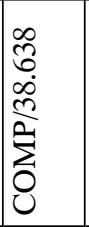 & 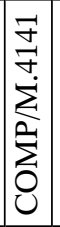 & 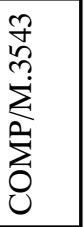 \\
\hline & -1 & $\sim$ & $m$ & $\nabla$ & $n$ & 0 & $r$ & $\infty$ & $a$ & $\stackrel{ }{ }$ & $\exists$ & $\stackrel{\simeq}{\simeq}$ & $\stackrel{m}{2}$ & \pm & $\stackrel{n}{2}$ \\
\hline
\end{tabular}


Table F: Regulatory (Article 7) proceedings in telecoms cases

\begin{tabular}{|c|c|l|c|l|c|}
\hline & Case no. & \multicolumn{1}{c|}{ Sector } & Legal basis & Decision & Date \\
\hline 1 & PL/2006/0524 & $\begin{array}{l}\text { Electronic } \\
\text { communications }\end{array}$ & $\begin{array}{l}\text { Article 7(4) } \\
\text { of Directive } \\
\text { 2002/21/EC }\end{array}$ & $\begin{array}{l}\text { Retail access to the public } \\
\text { telephone network at a fixed } \\
\text { location for non-residential } \\
\text { customers in Poland }\end{array}$ & 2007-01-10 \\
\hline 2 & PL/2006/0518 & $\begin{array}{l}\text { Electronic } \\
\text { communications }\end{array}$ & $\begin{array}{l}\text { Article 7(4) } \\
\text { of Directive } \\
\text { 2002/21/EC }\end{array}$ & $\begin{array}{l}\text { Retail access to the public } \\
\text { telephone network at a } \\
\text { fixed location for residential } \\
\text { customers }\end{array}$ & 2007-01-10 \\
\hline
\end{tabular}

Source: DG Information Society's website.

\section{Literature}

Andries A., Julien-Malvy B., 'The CISAC decision - creating competition between collecting societies for music rights' (2008) 3 Competition Policy Newsletter.

Bonova L., Koska D., Specker A., 'Consolidation of the EU airline industry: How the Commission kept seatbelts fastened in the 2009 airline merger wave' (2009) 3 Competition Policy Newsletter.

Drauz G., Chellingsworth T., Hyrkas N., 'Recent Developments in EC Merger Control' (2010) 1(1) Journal of European Competition Law and Practice.

\section{Annual reports}

European Commission's Annual Report on Competition Policy 2008

European Commission's Annual Report on Competition Policy 2009

Progress Report on the Single European Electronic Communications Market 2009 